\title{
The Features of Bali between its Beauty and Destruction in 1960-2014 Poetry
}

\author{
Puji Retno Hardiningtyas \\ Balai Bahasa Bali \\ Denpasar, Indonesia \\ pujiretnohardiningtyas@gmail.com
}

\author{
I Nyoman Darma Putra, I Nyoman Weda Kusuma, I \\ Gusti Ayu Agung Mas Triadnyani \\ Fakultas Ilmu Budaya \\ Universitas Udayana \\ Denpasar, Indonesia
}

\begin{abstract}
Various intellectual discourse of the features of Bali is characterized by a transition of poetry-writing style that tends to reveal well and bad of Bali in its time in five decades, between 1960 to 2014. The objective of this research is to analyze the Features of Bali between beauty and destruction in poems of Balinese poets published in 1960-2014. The data were collected using literature study method with critical reading technique and recorded corpus data taken from 19 poetry anthologies of Balinese poet. The method used to analyze data is analytical descriptive with interpretative technique. This study uses discourse theory and ecocritical theory with an interdisciplinary approach. The results and discussion of this study show that the poems of Balinese poet in 1960-2014 described the discourse of local knowledge of society about anthropocentrism and harmony of human with nature in Bali. The ecocultural nature of Bali's beauty and nature destruction includes (1) beautiful Balinese landscape and harmonious relationship between humans sourced from Hindu tri hita karana, (2) nature destruction such as conversion of agricultural land into tourism object, coastal damage, due to disaster, and the natural damage caused by humans. Thus, the poetry of Balinese poets in 1960-2014 is a reflection of social and environmental events of society as a track record of Bali from the beginning until now can be found through the art of poetry.
\end{abstract}

Keywords - discourse; environment; nature of Bali; beauty; destruction; ecocriticism

\section{INTRODUCTION}

The change of Bali in the early 21 st century was influenced by the dynamics of economic politics that occurred in Indonesia. In addition, since tourism was expressed in Bali, there are pressures on Bali that affect the lives of its people. The inner conflicts in Balinese society are a consequence of the transition process from agricultural economy to urban tourism [1]. Based on that context, there are interesting things that need to be discussed in this research, that is the dualism of natural discourse in Bali in the era of 1960s-2014. The Balinese poet has written about Bali and its changes since five decades ago. In 1960 - 1970 came the poems of the expression of Bali's natural beauty that was contradicted by the value of humanity and change of Bali environment. The Balinese poets, among them, are Ngurah Parsua, I Wayan Windia, I Made Taro, I Made Jara Atmaja, Gde Dharna, Faisal Baraas, I.G. Rachmat Supandi, Umbu Landu Paranggi, and I Gusti Putu Bawa Samar
Gantang. Another Balinese poet who consistently writes local Balinese-themed rhymes in the three decades, 1980s-2000s, are Gde Artawan, Putu Fajar Arcana, Sthiraprana Duarsa, Tan Lioe Ie, Nyoman Wirata, Made Adnyana Ole, Sindu Putra, Alit S. Rini, Mas Ruscitadewi, Oka Rusmini, I Made Suantha, K. Landras Syaelendra, Wayan Sunarta, and Ayu Winastri. Some of the names of poets outside Bali who also recorded his trace in writing about Bali in the last 50 years are IG. Rachmat Supandi, Faisal Baraas, Umbu Landu Paranggi, Lilik Mulyadi, Warih Wisatsana, Helmi Y. Haska, Saut Situmorang, and Acep Zamzam Noor.

Essentially, the poems of Balinese poets and outside Bali is indeed expressing the issue of Bali as a discourse that never ended to be discussed in various ways. Based on the problems in Bali contained in the poems of poets in Bali, the reasons for this research are as follows. First, the debate over Bali changes, one of them due to the growth of tourism which eventually led the Balinese poet to write the poetry-themed local color of the environment of Bali. Secondly, the Bali damage crisis that is packed in such a way as to be an attempt to rebel/social critic against the change. Third, the presence of awareness to preserve the beauty of Bali by documenting them through poems has been done by Balinese poet. This study discusses how the features of Bali between beauty and its damage are reflected in modern Indonesian poems in Bali 1960-2014. This study aims to reveal the description of the features of Bali and their environment in the poetry of 1960-2014 which theoretically contributes literary science, especially the literary period of poetry in Bali.

Previous studies that have studied several anthologies of poetry with the same title in A Literary Mirror: Balinese Reflections on Modernity and Identity in the Twentieth Century [2]. Besides poetry, the studies with ecocritical theory, both in national and international journals $[3,4,5,6,7,8,9,10,11]$. These earlier researchers became mindset and reference of this study that focused on the features of Bali between beauty and destruction in the poetry by Balinese poet.

The concept of discourse in this study is described in the view of Teun A. van Dijk [12]. The analysis of critical discourse on the text is shaped by the text itself, starting from the textual dimension of the text, the social cognitive dimension of the text-maker, and the social context dimension of its society through interaction and communication [12,13]. 
In this discourse, van Dijk uses a model that is called social cognition, a term adopted from this psychological approach explaining the structure and process of text formation [14]. Moreover, discourse consists of three dimensions that is text, cognition, and social context. In the texts are studied the structures and discourses that arise with various other social representations related to the social mindset, individual and community relationships, and micro and macro social structures $[15,16]$.

William Rueckert wrote an essay in 1978 entitled "Literature and Ecology and Experiment in Ecocriticism," which introduced the term ecocritical by emphasizing the treatise on nature. In the following year, Buell (1995) published the book Environmental Imagination, explaining the term "ecocriticism" [17] first officially came into our view, followed by Glottfelty and Fromm (1996) in his book The Ecocriticism Reader: Landmarks in Literary Ecology. "Ecocriticism offers a broad study approach and is recognized by a number of other designations, such as, "green cultural studies", "eco-poetics", and "environmental literary criticism". Since "ecocriticism is the study of the relationship between literature and the physical environment" [18]. Furthermore, Gerrard [19] states that "ecocriticism entails "the study of the relationship of the human and the non-human, throughout human cultural history and entailing critical analysis of the term "human" itself." Ecocritical meanings clearly talk about textual relationships between humans and non-humans, human and cultural histories related to the critical analysis of humans and their environment.

\section{RESEARCH METHOD}

The data source of this research is poems of Balinese poet published between the 1960s -2014. The data was taken from 19 joint anthologies and personal anthology that has been published in the 5 decades. The data is limited to poems that have the beauty and nature damage in Bali. Samples of the poems are taken as much as possible in the interest of research and prioritized on poems of poet who are quite prominent and influential by purposive sampling of the poems that represent the year 1960 - 2014 by taking 47 poems from 19 poets written by Balinese and non-Balinese poet. Most of these poems were published before the 2000s. Stages of analysis of this research are first, collecting the same theme poems by using the method of library research with critical reading techniques and notes. The existing data are classified by theme and then analyzed by the descriptive method of analysis with interpretative technique. Discourse theory of critical analysis van Dijk used to see that the text of poetry is a discourse of social cognition that occurs in society. Buell's ecocritical theory, Glotfelty, and Fromm, and Garrard with an interdisciplinary approach are used to analyze poetic data showing environmental conditions, both beauty and destruction, human and environmental relations, and human and non-human.

\section{RESULT AND DisCUSSION}

Based on the reading of the 1960-2014 poems, there are 48 poems that describe the features of Bali from the point of view of beauty and damage. The poems are listed in table I below.
TABLE I. BEAUTY AND DAMAGE OF BALI POEMS

\begin{tabular}{|c|c|c|c|}
\hline \multirow[b]{2}{*}{ Poet } & \multicolumn{3}{|c|}{ Anthology of Poetry } \\
\hline & Poetry Title & $\begin{array}{l}\text { Year, } \\
\text { page }\end{array}$ & Issue \\
\hline $\begin{array}{l}\text { Made } \\
\text { Adyana Ole } \\
{[20]}\end{array}$ & $\begin{array}{l}\text { Desa } \\
\text { Palasari, } \\
\text { Jembrana }\end{array}$ & 2914 & $\begin{array}{l}\text { Konflik pembangunan } \\
\text { bendungan }\end{array}$ \\
\hline $\begin{array}{l}\text { Gde } \\
\text { Artawan } \\
{[21]}\end{array}$ & $\begin{array}{l}\text { Di Kota } \\
\text { Singaraja }\end{array}$ & $\begin{array}{l}2014 \\
95-96\end{array}$ & $\begin{array}{l}\text { Perubahan kota akibat } \\
\text { tanah sawah terjual }\end{array}$ \\
\hline $\begin{array}{l}\text { I G.P.B. } \\
\text { Samar } \\
\text { Gantang } \\
{[22]}\end{array}$ & $\begin{array}{l}\text { Bendung } \\
\text { Kota Pala }\end{array}$ & $\begin{array}{l}2013 \\
140\end{array}$ & $\begin{array}{l}\text { Dampak pembanguna } \\
\text { bendungan }\end{array}$ \\
\hline $\begin{array}{l}\text { I G.P.B. } \\
\text { Samar } \\
\text { Gantang } \\
{[23]}\end{array}$ & Bukit Pecatu & $\begin{array}{l}2013 ; \\
26 ; \\
1976 ; 3\end{array}$ & $\begin{array}{l}\text { Gambaran bukit yang } \\
\text { tandus di tengah hingar } \\
\text { binger bandara Tuban } \\
\text { dan pelabuhan Benoa }\end{array}$ \\
\hline $\begin{array}{l}\text { I G.P.B. } \\
\text { Samar } \\
\text { Gantang } \\
{[23]}\end{array}$ & $\begin{array}{l}\text { Gua } \\
\text { Bedugul }\end{array}$ & $\begin{array}{l}2013 ; \\
27 ; \\
1976 ; 5\end{array}$ & $\begin{array}{l}\text { Keindahan alam gua di } \\
\text { Bedugul }\end{array}$ \\
\hline $\begin{array}{l}\text { I G.P.B. } \\
\text { Samar } \\
\text { Gantang } \\
{[23]}\end{array}$ & $\begin{array}{l}\text { Pagi Buta di } \\
\text { Pantai Kuta }\end{array}$ & $\begin{array}{l}2013 ; \\
28 ; \\
1976 ; 6\end{array}$ & $\begin{array}{l}\text { Keindahan Kuta di pagi } \\
\text { hari }\end{array}$ \\
\hline $\begin{array}{l}\text { I G.P.B. } \\
\text { Samar } \\
\text { Gantang } \\
{[23]}\end{array}$ & $\begin{array}{l}\text { Tabanan I, } \\
\text { Tabanan II }\end{array}$ & $\begin{array}{l}2013 \\
30,31 \\
1976 ; \\
10,11 \\
\end{array}$ & $\begin{array}{l}\text { Gambaran kota Tabanan } \\
\text { yang jauh dari kota }\end{array}$ \\
\hline $\begin{array}{l}\text { Putu Fajar } \\
\text { Arcana [24] }\end{array}$ & $\begin{array}{l}\text { Jalanan } \\
\text { Denpasar }\end{array}$ & $\begin{array}{l}2012 \\
16\end{array}$ & $\begin{array}{l}\text { Denpasar yang } \\
\text { kehilangan tata ruang } \\
\text { kota }\end{array}$ \\
\hline $\begin{array}{l}\text { Stiraprana } \\
\text { Duarsa [25] }\end{array}$ & Mertasari & $\begin{array}{l}2012 \\
39\end{array}$ & $\begin{array}{l}\text { Gambaran kerusakan } \\
\text { kota di tengah pantai } \\
\text { yang indah }\end{array}$ \\
\hline $\begin{array}{l}\text { Tan Lioe Ie } \\
{[26,27]}\end{array}$ & $\begin{array}{l}\text { Malam di } \\
\text { Pasar } \\
\text { Kumbasari }\end{array}$ & $\begin{array}{l}2012 \\
59 \\
2000 \\
85 \\
\end{array}$ & $\begin{array}{l}\text { Pemandangan pasar } \\
\text { Kumbasari di malam hari }\end{array}$ \\
\hline $\begin{array}{l}\text { Lilik } \\
\text { Mulyadi [28] }\end{array}$ & $\begin{array}{l}\text { Selamat } \\
\text { Malam Kota } \\
\text { Denpasar }\end{array}$ & $\begin{array}{l}2012 ; \\
66\end{array}$ & $\begin{array}{l}\text { Kota yang dirindukan } \\
\text { antara kemajuan dan } \\
\text { tradisi }\end{array}$ \\
\hline $\begin{array}{l}\text { Ketut Nena } \\
{[29]}\end{array}$ & Sanur & $\begin{array}{l}2012 \\
69\end{array}$ & $\begin{array}{l}\text { Keindahan Sanur dan } \\
\text { ikon pariwisata }\end{array}$ \\
\hline $\begin{array}{l}\text { Umbu Landu } \\
\text { Paranggi [30] }\end{array}$ & $\begin{array}{l}\text { Denpasar } \\
\text { Selatan, dari } \\
\text { Sebuah } \\
\text { Lorong } \\
\end{array}$ & $\begin{array}{l}2012 \\
70\end{array}$ & $\begin{array}{l}\text { Kota metropolitan yang } \\
\text { meninggalkan } \\
\text { kesenjangan }\end{array}$ \\
\hline $\begin{array}{l}\text { Sindhu Putra } \\
\text { [31] }\end{array}$ & $\begin{array}{l}\text { Denpasar } \\
\text { Kilometer } \\
\text { Nol }\end{array}$ & $\begin{array}{l}2012 \\
86\end{array}$ & $\begin{array}{l}\text { Kota yang riuh } \\
\text { kehilangan jati diri }\end{array}$ \\
\hline $\begin{array}{l}\text { Alit S. Rini } \\
\text { [32] }\end{array}$ & $\begin{array}{l}\text { Sihir } \\
\text { Denpasar }\end{array}$ & $\begin{array}{l}2012 \\
93\end{array}$ & $\begin{array}{l}\text { Perubahan kota yang } \\
\text { macet dan penuh } \\
\text { kesejahteraan semu }\end{array}$ \\
\hline $\begin{array}{l}\text { Mas } \\
\text { Ruscitadewi } \\
{[33,34]}\end{array}$ & Denpasar & $\begin{array}{l}2012 ; \\
99 ; \\
2000 ; 5\end{array}$ & $\begin{array}{l}\text { Denpasar penuh cerita } \\
\text { sejarah }\end{array}$ \\
\hline $\begin{array}{l}\text { Oka Rusmini } \\
\text { [35] }\end{array}$ & Sanur & $\begin{array}{l}2012 \\
101\end{array}$ & $\begin{array}{l}\text { Sanur yang telah tergerus } \\
\text { pembangunan hotel }\end{array}$ \\
\hline $\begin{array}{l}\text { I Made } \\
\text { Suantha [36] }\end{array}$ & $\begin{array}{l}\text { Ekuilibrium } \\
\text { Denpasar }\end{array}$ & $\begin{array}{l}2012 \\
103\end{array}$ & $\begin{array}{l}\text { Denpasar yang tinggal } \\
\text { kenangan; sawah beralih } \\
\text { fungsi }\end{array}$ \\
\hline $\begin{array}{l}\text { Wayan } \\
\text { Sunarta [37] }\end{array}$ & Denpasar & $\begin{array}{l}2012 ; \\
111\end{array}$ & $\begin{array}{l}\text { Kota Denpasar yang telah } \\
\text { berubah }\end{array}$ \\
\hline $\begin{array}{l}\text { K. Landras } \\
\text { Syaelendra } \\
{[38]}\end{array}$ & $\begin{array}{l}\text { Fragmen } \\
\text { Pasar } \\
\text { Malam } \\
\text { Kumbasari } \\
\end{array}$ & $\begin{array}{l}2012 \\
121\end{array}$ & $\begin{array}{l}\text { Suasana pasar Kumbasari } \\
\text { adalah kehidupan } \\
\text { perempuan }\end{array}$ \\
\hline $\begin{array}{l}\text { Ayu Winastri } \\
{[39]}\end{array}$ & Kumbasari & $\begin{array}{l}2012 \\
132\end{array}$ & $\begin{array}{l}\text { Pemandangan pasar } \\
\text { Kumbasari yang dipenuhi }\end{array}$ \\
\hline
\end{tabular}




\begin{tabular}{|c|c|c|c|}
\hline \multirow[b]{2}{*}{ Poet } & \multicolumn{3}{|c|}{ Anthology of Poetry } \\
\hline & Poetry Title & $\begin{array}{l}\text { Year, } \\
\text { page }\end{array}$ & Issue \\
\hline & & & perempuan kuat \\
\hline $\begin{array}{l}\text { I Nyoman } \\
\text { Wirata [40] }\end{array}$ & $\begin{array}{l}\text { Di Taman } \\
\text { Kota, } \\
\text { Sebatang } \\
\text { Pohon Tak } \\
\text { Kutahu } \\
\text { Namanya }\end{array}$ & $\begin{array}{l}2012 \\
136\end{array}$ & $\begin{array}{l}\text { Sawah-sawah habis } \\
\text { dibangun taman kota }\end{array}$ \\
\hline $\begin{array}{l}\text { Acep } \\
\text { Zamzam } \\
\text { Noor [41] } \\
\end{array}$ & $\begin{array}{l}\text { Pasar } \\
\text { Kumbasari, } \\
\text { Denpasar }\end{array}$ & $\begin{array}{l}2012 \\
147\end{array}$ & $\begin{array}{l}\text { Pemandangan malam di } \\
\text { pasar Kumbasari }\end{array}$ \\
\hline $\begin{array}{l}\text { Oka } \\
\text { Rusmini } \\
{[42]}\end{array}$ & Kintamani & $\begin{array}{l}2003 \\
120\end{array}$ & $\begin{array}{l}\text { Gambaran Kintamani, } \\
\text { gunung dan danau Batur }\end{array}$ \\
\hline $\begin{array}{l}\text { K. Landras } \\
\text { Syaelendra }\end{array}$ & $\begin{array}{l}\text { Di Pura } \\
\text { Tanah Lot }\end{array}$ & $\begin{array}{l}2000 \\
49 \\
1994\end{array}$ & $\begin{array}{l}\text { Pembangunan di sekitar } \\
\text { Pura Tanah Lot }\end{array}$ \\
\hline $\begin{array}{l}\text { Warih } \\
\text { Wisatsana } \\
\text { [43] }\end{array}$ & $\begin{array}{l}\text { Jalan ke } \\
\text { Tanah Lot }\end{array}$ & $\begin{array}{l}2000 \\
71\end{array}$ & $\begin{array}{l}\text { Penebangan pohon untuk } \\
\text { pembangunan dan tanah } \\
\text { persawahan dibangun } \\
\text { hotel-hotel }\end{array}$ \\
\hline $\begin{array}{l}\text { Helmi Y. } \\
\text { Haska [44] }\end{array}$ & $\begin{array}{l}\text { Jembatan } \\
\text { Campuhan }\end{array}$ & $\begin{array}{l}2000 \\
109\end{array}$ & $\begin{array}{l}\text { Keasrian sungai di bawah } \\
\text { jembatan }\end{array}$ \\
\hline $\begin{array}{l}\text { Saut } \\
\text { Situmorang } \\
{[45]}\end{array}$ & Arak Bali & $\begin{array}{l}2000 \\
119\end{array}$ & $\begin{array}{l}\text { Perubahan kehidupan di } \\
\text { Bali yang terbuka untuk } \\
\text { wisatawan }\end{array}$ \\
\hline $\begin{array}{l}\text { Ngurah } \\
\text { Parsua [46] }\end{array}$ & Kepada Bali & $\begin{array}{l}1987 \\
40\end{array}$ & $\begin{array}{l}\text { Harapan kepada Bali } \\
\text { tetap berpegang tradisi }\end{array}$ \\
\hline $\begin{array}{l}\text { Ngurah } \\
\text { Parsua [47] }\end{array}$ & Batur & $\begin{array}{l}1982 ; \\
40--42\end{array}$ & $\begin{array}{l}\text { Gambaran Batur yang } \\
\text { subur, meski persoalan } \\
\text { sosial tetap harus dilalui }\end{array}$ \\
\hline $\begin{array}{l}\text { I G.P.B. } \\
\text { Samar } \\
\text { Gantang }\end{array}$ & $\begin{array}{l}\text { Pantai } \\
\text { Kelanting }\end{array}$ & $\begin{array}{l}2013 \\
54 \\
1979 \\
16 \\
\end{array}$ & $\begin{array}{l}\text { Pantai yang masih asri } \\
\text { untuk bermain anak-anak }\end{array}$ \\
\hline $\begin{array}{l}\text { I.G. } \\
\text { Rahchmat } \\
\text { Supandi } \\
{[48]}\end{array}$ & $\begin{array}{l}\text { Di } \\
\text { Persimpanga } \\
\text { n Bukit } \\
\text { Pecatu }\end{array}$ & $\begin{array}{l}1975 \\
17\end{array}$ & $\begin{array}{l}\text { Di balik panorama indah } \\
\text { ada kesedihan }\end{array}$ \\
\hline $\begin{array}{l}\text { I.G. } \\
\text { Rahchmat } \\
\text { Supandi } \\
{[49]}\end{array}$ & $\begin{array}{l}\text { Malam } \\
\text { Terang } \\
\text { Bulan di } \\
\text { Pantai Kuta }\end{array}$ & $\begin{array}{l}1975 \\
20\end{array}$ & $\begin{array}{l}\text { Keindahan Pantai Kuta } \\
\text { dan lingkungannya yang } \\
\text { mengalami pergeseran } \\
\text { nilai kehidupan }\end{array}$ \\
\hline $\begin{array}{l}\text { I.G. } \\
\text { Rahchmat } \\
\text { Supandi }\end{array}$ & Kerambitan & $\begin{array}{l}1974 ; \\
16\end{array}$ & $\begin{array}{l}\text { Panorama alam di Desa } \\
\text { Kerambitan }\end{array}$ \\
\hline $\begin{array}{l}\text { I.G. } \\
\text { Rahchmat } \\
\text { Supandi }\end{array}$ & Pantai Kuta & $\begin{array}{l}1974 ; \\
13\end{array}$ & $\begin{array}{l}\text { Suasana Pantai Kuta } \\
\text { sebagai kawasan } \\
\text { pariwisata }\end{array}$ \\
\hline $\begin{array}{l}\text { I Wayan } \\
\text { Windia [50] }\end{array}$ & Sukawati & $1974 ; 9$ & $\begin{array}{l}\text { Sebuah desa yang kering } \\
\text { dan tanpa penghasilan } \\
\text { untuk warganya }\end{array}$ \\
\hline $\begin{array}{l}\text { I Wayan } \\
\text { Windia [50] }\end{array}$ & $\begin{array}{l}\text { Balada } \\
\text { Orang }^{2} \\
\text { Trunyan }\end{array}$ & $1974 ; 8$ & $\begin{array}{l}\text { Gambaran desa asli Bali } \\
\text { Mula di bawah bukit } \\
\text { yang sepi pekerjaan }\end{array}$ \\
\hline $\begin{array}{l}\text { I Wayan } \\
\text { Windia [50] }\end{array}$ & Kamasan & $\begin{array}{l}1974 ; \\
14\end{array}$ & $\begin{array}{l}\text { Gambaran sebuah desa } \\
\text { yang sepi dan asri }\end{array}$ \\
\hline $\begin{array}{l}\text { I Made Jaro } \\
\text { Atmaja [51] }\end{array}$ & Denpasar & $1973 ; 8$ & $\begin{array}{l}\text { Kesenjangan masyarakat } \\
\text { akibat perubahan kota }\end{array}$ \\
\hline $\begin{array}{l}\text { Made Taro } \\
{[52]}\end{array}$ & $\begin{array}{ll}\text { Oleh }^{2} & \text { dari } \\
\text { Bali } & \\
\end{array}$ & $1973 ; 4$ & $\begin{array}{l}\text { Keindahan Tanah Lot dan } \\
\text { alam di Bali }\end{array}$ \\
\hline $\begin{array}{l}\text { I.G. } \\
\text { Rahchmat } \\
\text { Supandi } \\
\text { [53] }\end{array}$ & $\begin{array}{l}\text { Kemarau di } \\
\text { Bukit Pecatu }\end{array}$ & $\begin{array}{l}1973 ; \\
14\end{array}$ & $\begin{array}{l}\text { Kekeringan di Bukit } \\
\text { Pecatu }\end{array}$ \\
\hline $\begin{array}{l}\text { Faisal } \\
\text { Baraas [54] }\end{array}$ & $\begin{array}{l}\text { Di } \\
\text { Pelabuhan } \\
\text { Buleleng } \\
\end{array}$ & $1973 ; 5$ & $\begin{array}{l}\text { Situasi dan kondisi yang } \\
\text { panas bagi pekerja buruh } \\
\text { di Pelabuhan Buleleng }\end{array}$ \\
\hline
\end{tabular}

\begin{tabular}{|l|l|l|l|}
\hline \multirow{2}{*}{ Poet } & \multicolumn{3}{|c|}{ Anthology of Poetry } \\
\cline { 2 - 4 } & Poetry Title & $\begin{array}{c}\text { Year, } \\
\text { page }\end{array}$ & \multicolumn{1}{c|}{ Issue } \\
\hline $\begin{array}{l}\text { Ngurah } \\
\text { Parsua [55] }\end{array}$ & Bedugul & $1973 ; 5$ & $\begin{array}{l}\text { Ketenangan di Danau } \\
\text { Bedugul }\end{array}$ \\
\hline $\begin{array}{l}\text { Nyoman } \\
\text { Sutjipta [56] }\end{array}$ & $\begin{array}{l}\text { Danau } \\
\text { Bedugul }\end{array}$ & $\begin{array}{l}1969 ; \\
41\end{array}$ & $\begin{array}{l}\text { Suasana tenang dan } \\
\text { keindahan alam di Danau } \\
\text { Bedugul }\end{array}$ \\
\hline $\begin{array}{l}\text { Ninik Berata } \\
\text { [57] }\end{array}$ & $\begin{array}{l}\text { Sendja di } \\
\text { Pantai }\end{array}$ & $\begin{array}{l}1969 ; \\
20\end{array}$ & $\begin{array}{l}\text { Keindahan pantai di } \\
\text { Buleleng menjadi saksi } \\
\text { kegundahan manusia }\end{array}$ \\
\hline $\begin{array}{l}\text { Yudha } \\
\text { Paniek [58] }\end{array}$ & Kepada Bali & $\begin{array}{l}1969 ; \\
15\end{array}$ & $\begin{array}{l}\text { Rasa cinta terhadap Bali } \\
\text { dapat diukur melalui diri } \\
\text { sendiri }\end{array}$ \\
\hline $\begin{array}{l}\text { Faisal } \\
\text { Baraas [59] }\end{array}$ & Kintamani & $\begin{array}{l}1969 ; \\
12\end{array}$ & $\begin{array}{l}\text { Kintamani yang penuh } \\
\text { kabut }\end{array}$ \\
\hline $\begin{array}{l}\text { Gde Dharna } \\
\text { [60] }\end{array}$ & Kepada Bali & $\begin{array}{l}1969 ; \\
10\end{array}$ & $\begin{array}{l}\text { Harapan ketenangan dan } \\
\text { keindahan untuk Bali } \\
\text { tetap terjaga }\end{array}$ \\
\hline
\end{tabular}

From the table, found 16 poems about the beauty of nature that are written by 16 poets and 32 poems about the destruction that are written by 26 poets. From the 48 poems about the features of Bali, in general, the poems describe the damage to the Balinese environment that impact on the life of Balinese people themselves.

\section{A. The Features of Bali as a Form of Community Discourse}

The decade $1960-2000$ s poems was the rise of social protest poems as the effect of changes in Bali, both of which occurred due to natural disasters, human activities, local government policies, tourism, and the fate from God. In the literary texts, the diction of poets depicting the area of Bali written in different times apparently shows a common theme. Some of the diction chosen in 48 poems were used in the social context by the poet. The choice of diction depends on the ideology of the poet, both of beauty and the nature damage of the poem displayed in the table. When it is observed from 48 poems, the diction tends to be used to provide a negative image. In the year of $1960-2014$ found the same title of poetry written by different poets. Despite reaching more than 50 years, the problem of Bali change is still expressed by the poet in Bali in their poems. From the 48 poems, the social discourse written by the poet can be classified into six discourses that were risen from the events in Balinese society, that are (1) the construction of the reservoir conflict in Palasari village, (2) the change of city due to tourism and immigrants, (3 conversion of rice fields into hospitality land (4) dry nature conditions, (5) Balinese natural beauty, especially the beaches, and (6) Balinese economy.

As an example, in this discussion, the first, second, and third discourses will be analyzed as follows. In relation to the poems that are born from the public discourse, especially the social interactions of society and the environment have shaped the socio-cultural activities of society itself. This appears in the poem titled "Desa Palasari, Jembrana" by Made Adnyana Ole and "Bendungan Kota Pala" (I G.P. Bawa Samar Gantang) which was born by his poet because he saw the social phenomenon that occurred in Jembrana society. The discourse of the construction of a reservoir in the village of Palasari, Jembrana is an event that occurred 22 years ago. As an individual, Samar Gantang is very sensitive to the social events that occurred. Similarly, Made Adnyana Ole who just wrote the 
discourse of the construction of the Palasari Village reservoir in 1996, although the issue of the reservoir construction happened in 1986.

Social facts that are conceptualized as mental structures are encompassed in the view of human, social role, or social event. The aesthetic shift of Balinese poets from idealistic romantics to social issues/ Balinese changes occurred and marked by a major change of government policy in the late 1980s [11]. The local government gives deregulation in the banking sector and receives capital help from the investor in Bali and occurred massive development tourism industry. The same thing was done by the poets that opposed government policy by writing poetry. Consider the poem I G.P.B Samar Gantang "Bukit Pecatu", Umbu Landu Paranggi "Denpasar Selatan, dari Sebuah Lorong ...", Alit S. Rini "Sihir Denpasar", Putu Fajar Arcana "Jalanan Denpasar", K. Landras Syaelendra "Di Pura Tanah Lot ", Oka Rusmini "Sanur", and Stiraprana Duarsa" Mertasari ". Their poems expressed the city changes due to tourism and immigrants, such as the poem "Sanur" by Oka Rusmini /Aku telah kehilangan pantaiku, orang-orang terus berdatangan/menanam beragam pohon-pohon asing berbatu/. The diction chosen by the poet is very appropriate to convey the dissatisfaction/protest against the uncontrolled hotel construction in Bali.

In the early 1990s to 2000s, the construction of hotels is very rapid in Bali. Agricultural reserves are getting smaller and thinner. This land issue is packed with poets in the following poems. In 1996 Warih Wisatsana writes the poem "Jalan ke Tanah Lot" and K. Landras Syaelendra "Di Pura Tanah Lot", it is very clear that the exploitation of the land around Tanah Lot at that time became the poet's inspiration in his poem, such as /Kami memasuki kawasan asing ini/ di antara tiang-tiang beton/. The cognitive process of poets is shaped because of the environment, in the exploited natural phenomena, the poem becomes a witness to the historical changes of a city or region. Based on the poetry produced by poets in Bali, it can be concluded that events occurring within society influence the sociological knowledge that follows the poet's mind to write poems in the context of what happened at the time.

\section{B. The Features of Bali between Beauty and Environment Damage}

Basically, reading the poetry of Balinese poets in 19602014 , the reader needs to understand the dichotomy/dualism of meaning. On the one hand, the poet expresses the beauty of nature, on the other hand, the poems convey the voice of anxiety, concern, and alienation of Balinese people in their own territory. This section describes the ecocritical analysis of poems that reveal the Balinese environment, both beauty and destruction. The first phase of this analysis looks at the beauty of the environment that humans do with nature. Here are some poems with the theme of Bali's beauty and environmental damage, specifically discussed with ecocritic theory that shows the attitude of respect for nature with a critical poet poured in his poem. Three poems of nature's beauty are "Kerambitan" by IG. Rachmat Supandi, "Danau Bedugul" by Nyoman Sutjipta, and "Sendja di Pantai Buleleng" by Ninik Berata.
In the "Kerambitan" the poet represents the natural scenery of Kerambitan Village. This poem is very clear showing the village environment that still there are rice fields stretched, green trees, and peaceful atmosphere. The fertile and prosperous imagery of nature, agriculture and farming culture, and the ecosphere nature of Kerambitan characterized by winding, rocky, steep roads, clear skies, clear streams, and teenage girls engrossed in water, and pollution-free is the dominant image in poem "Kerambitan". The lyrics depicted are the natural paintings of villages in the 1970s, /liku-liku jalan terjal berbatu/ mendaki dan menurun/.../langit cerah awan gemawan/hijau pepohonan, hijau persawahan/cuaca hening dan tentram/.../anak-anak kampung lari kejar-kejaran/sembari bersiul di punggung kerbau/.../di kali, gadis-gadis perawan telanjang mandi/.../Krambitan, desa para dewi-dewi, yang/diciptakan Tuhan, buat umat-Nya, buat jejaka/yang beruntung [49]. The "Kerambitan" shows the nature, culture, and nurture of villages away from urban areas, peaceful atmosphere, and many trees surrounding the village. The words sawah, langit cerah, hijau pepohonan, di sungai, Krambitan, desa para dewi-dewi are an allusion to a peaceful and fertile dwelling place. Similar views are also found in the poem "Danau Bedugul" by Nyoman Sutjipta, the beauty of the lake environment is clearly seen. Like the following quote /digunung itu angin menjelinap meriakkan air danau/kupatju lari rinduku di danau Bedugul/.../tahukah kau tjintamu kubawa berlajar diatas danau/ [56]. The poem also demands an understanding of nature, culture, and nurture in Bedugul. The phrase of the lake can be seen in Ngurah Parsua poem titled "Bedugul" when it is paired, the two poems show the similarity of theme and a peaceful nature imagery in a famous lake in Bali. The quotation of Ngurah Parsua poem is an imagery of mountains, the land of Bali which has a panorama of Lake Bedugul and the existence of Pura Ulun Danu Beratan give more image of tourism objects in Bali, /keristal sepi angin meluluhkan bayangan/kemuning sunyi danau lenggang tenang/semua asyik bersiul sendiri-sendiri/ [55]. The beauty of beach and sea in Buleleng is also beautifully described by Ninik Berata in the "Sendja di Pantai Buleleng". Through the diction of laut, ombak, karang, gundukan pasir, and gemuruhnya ombak di pantai Buleleng, the poet expressed the local Balinese ecosphere, such as /ahoi, indahnja laut diwaktu sendja/ombak di bulan desember menampar-nampar tepian djambatan/mengelus karang, lalu mentjium gundukan pasir/ (Berata, 1969: 20). Thus, nature and culture in Bali can be said to synergize well if there is nurture in it.

The second stage, the analysis of poems reflecting Bali's nature destruction. The poem with the theme of nature destruction in Bali discussed is "Di Taman Kota, Sebatang Pohon Tak Kutahu Namanya" by I Nyoman Wirata, "Di Pura Tanah Lot" by K. Landras Syaelendra, "Bukit Pecatu" by I. G.P.B. Samar Gantang, "Sanur" Oka Rusmini, and "Sanur" by Ketut Nena. In general, the phenomenon of natural destruction cannot be separated from the destructive actions of human himself. The poem "Di Taman Kota, Sebatang Pohon Tak Kutahu Namanya" by I Nyoman Wirata dominated the image of the city of Denpasar that has decreased the quality of the environment. At the end of the verse, I Nyoman Wirata describes /pada ruang yang dipagari garis-garis yang tipis/seperti petak pematang dan rasa lumpur yang 
subur/Menyadarkan aku ini sapi pembajak/petani yang akan kehilangan sawah-sawahnya [40] as figurative issues of land in Bali that are increasingly narrow. Moreover, the city as an arena of cultural and cultural binary contestation of economic, social, political, and human cultural innovations that change the ecology of the city. Notice other poems with the same theme and expressing the shift of urban planning and the space of Denpasar City (see table).

It is often not realized that the destruction of nature, one of which is caused by human intervention and cultural change. In the "Di Pura Tanah Lot" by K. Landras Syaelendra, with a nostalgic style invites reader to see Tanah Lot which once was silent, quiet, and where people pray in certain ceremonies, now it becomes a land of foreign investors to build hotels, villa or resort worth billions of rupiah. Here are the first two lines in the first verse, /Kami masuki kawasan asing ini/Di antara tiangtiang beton/Dan lalu lalang tubuh-tubuh/Telanjang/ [38]. Note also the poem "Bukit Pecatu" by I.G.P.B. Samar Gantang is an imagery of a dry, barren, and untouched condition that is different from Tuban, Benoa, and Sanggaran as three heavenly goddesses.

The poem "Sanur" by Oka Rusmini and "Sanur" by Ketut Nena became a metaphorical environmental landscape. In 1970s, dokar was the main transportation of the people in Bali. This poem is a representation of the pain, suffering, and destruction of Sanur beach. Local people began to lose their identity because of the change and growth of the tourism industry in Denpasar encourages new development, the urban from Sanur. Bali is no longer a community that prioritizes agriculture [1]. In 2005, half of Bali's population lives in urban areas. In 1990, the beginning of massive urbanization happened, there were $26 \%$ of residents living in Denpasar, including Sanur. The description is explained in the fifth stanza /Tak ada rasa sunyi yang begitu hening/Orang-orang datang memasang tenda-tenda. Menawarkan beragam barang/Pasar? /Aku telah kehilangan pantaiku, orang-orang terus berdatangan menanam beragam pohon-pohon asing berbatu/Menguncinya rapat-rapat semua lubang pintu/. The quotation of the verse is a representation of the natural damage caused by tourism and urbanization. The environmental damage in Bali in the poem shows that Balinese have forgotten the Hindu cosmology concept, namely trihita karana. The poems are equally expressing environmental crises caused by capitalism, government policies, and the tourism sector on the environment.

\section{CONCLUSION}

Based on these descriptions, it can be concluded that fortytwo poets in the five-decake range still proposed the same issue: environmental damage in some areas of Bali and the beauty of Bali's natural panorama. In this ecocriticism critic, poems of Balinese poet connect the discourse and reality of the natural environment that grows the culture of production and economic assets of the people of Bali. From the 48 poems, the reader gets two interesting discourses. Firstly, the poets in Bali are very capable in describing nature as a harmonization between the microcosm and the macrocosm in Bali although the poem is a social critique of the loss of land and the destruction of the beaches in Bali. Secondly, as a literary work, poems of Balinese poets make an important contribution to the treasures of modern Indonesian poetry in Indonesia, especially environmental-oriented studies in Bali.

\section{ACKNOWLEDGMENT}

Thanks to Prof. Dr. I Nyoman Darma Putra, M.Litt. (Promotor), Prof. Dr. I Nyoman Weda Kusuma, M.S. (Copromotor 1), and Dr. I Gusti Ayu Agung Mas Triadnyani, S.S., M. Hum. (Co-promotor 2) that has guided the author.

\section{REFERENCES}

[1] H. Schulte Nordholt, Bali Benteng Terbuka 1995-2005: Otonomi Daerah, Demokrasi ELektoral, dan Identitas-Identitas Defensif. Denpasar: Pustaka Larasan, 2010.

[2] I.N.D. Putra, A Literary Mirror: Balinese Reflections on Modernity and Identity in the Twentieth Century. Leiden: KITLV Press, 2011.

[3] E. Sultana, "Wordsworth's the Prelude: A Manifesto of Ecocriticism," Journal of Literature, Languages and Linguistics, vol. 19, pp. 7-10, 2006

[4] P.R. Hardiningtyas, "Masalah Tanah dan Krisis Lingkungan di Bali dalam Antologi Puisi Dongeng dari Utara Karya Made Adnyana Ole,' Journal Atavisme, vol. 19, no. 1, pp. 45-59, Juni 2016 http://atavisme.web.id/index.php/atavisme/article/view/180/176.

[5] D. Alfianti. "Kerusakan Hutan sebagai Pengetahuan Bersama dalam Perspektif Sosiokognitif Teun A. van Dijk (Analisis Wacana Kritis Kumpulan Puisi "KOnser Kecemasan" Karya Penyair Kalimantan Selatan), Ecology of Language and Literature: Seminar Proceedings, Banjarmasin: Program Studi Pendidikan Bahasa Inggris, pp. 45-65, Maret 2015

[6] I.B. Utomo, "Keruskaan Alam Kalimantan Timur di Mata Sastrawan Lokal,” Journal Atavisme, vol. 17, no. 1, pp. 17-28, Juni 2014. http://atavisme.web.id/index.php/atavisme/article/view/16/14

[7] M.M. Miah, "Wordsworth's Nature Poetry: An Eco-Scientific Perspective," Sino-US English Teaching, vol. 9, no. 12, pp. 1793-1800, Desember 2012

[8] Harsono, "Ekokritik: Kritik Sastra Berwawasan Lingkungan," Majalah Kajian Sastra jurnal Bidang Kebahasaan dan Kesastraan, vol. 32, no. 1, pp. 31-50, Januari 2008. e-journal.undip.ac.id.

[9] J. Tošić, "Ecocriticism-Interdisciplinary Studi of Lterature and Environment," Facta Universitatis, Series: Working and Living Environmental Protection, vol 3, no. 1, pp. 43-50, 2006.

[10] D. Phillips, "Ecocriticism, Literary Theory, and the Truth of Ecology," Source: New Literary History, vol. 30, no. 3, Ecocriticism, pp. 577-602. The Johns Hopkins University Press, 1999 http://www.jstor.org/stable/20057556.

[11] I.N.D. Putra, "Sajak Protes Penyair Bali 1990-an," Proses dan Protes Budaya Persembahan Ngurah Bagus, Ed. Aron Meko Mbete at all, Denpasar: PT Bali Post bekerja sama dengan Balai Penelitian Bahasa Denpsara, pp. 143-165, 1998.

[12] T.A. van Dijk, Aims of Critical Discours \& Analysis. Japan Discourse, vol. 1, p. 17, 1995.

[13] Eriyanto, Analisis Wacana: Pengantar Analisis Teks Media, Yogyakarta: LKis, 2001

[14] A. Sobur, Analisis Teks Media: Suatu Pengantar untuk Analisis Wacana, Analisis Semiotik, dan Analisis Farming, Bandung: Remaja Rosdakarya, 2006

[15] T.A. van Dijk, Discourse and Society. London: Newbury Park and New Delhi Sage, Vol 4 (2), p. 249, 1993.

[16] T.A. van Dijk, Critical Discourse Studies: A Sociocognitive Approach, London: Sage, p. 66-67, 2002.

[17] L. Buell, The Environmental Imagination: Thoreau Nature Writing and the Formation of American Culture. Cambridge: Belknap Press of Harvard University Press, 1995.

[18] C. Glottfelty and H. Fromm, The Ecocriticism Reader: Landmarks in Literary Ecology, London: University of Georgia Press, 1996. 
[19] G. Gerrard, Ecocriticism, New York: Routledge, 2004.

[20] M.A. Ole, "Desa Palasari, Jembrana” Dongeng dari Utara, Yogyakarta: Akar Indonesia, p. 29, 2014.

[21] G. Artawan, “Di Kota Singaraja,” Tubuhku Luka Pesisir Tubuhmu Luka Pengunungan, Singaraja: Mahima Institut, pp. 95-96, 2014.

[22] I.G.P.B.S. Gantang, "Bendung Kota Pala," "Bukit Pecatu," "Gua Bedugul," "Pagi Buta di Pantai Kuta," "Tabanan I, Tabanan II," "Pantai Kelanting," Leak Jagat: Sajak-Sajak 1973-2013, Magelang: Waktoe, 2013.

[23] I.G.P.B.S. Gantang, "Bendung Kota Pala," "Bukit Pecatu," "Gua Bedugul," "Pagi Buta di Pantai Kuta," "Tabanan I, Tabanan II," "Pantai Kelanting," Kisah Sebuah Kota Pelangi, Denpasar: Lembaga Seniman Indonesia Bali, 1976.

[24] P.F. Arcana. “Jalanan Denpasar,” Dendang Denpasar Nyiur Sanur, Eds. I Nyoman Darma Putra et al, Denpasar: Pemerintah Kota Denpasar bekerja sama dengan Arti Foundation, p. 16, 2012.

[25] S. Duarsa, "Mertasari," Dendang Denpasar Nyiur Sanur. Eds. I Nyoman Darma Putra et al, Denpasar: Pemerintah Kota Denpasar bekerja sama dengan Arti Foundation, p. 39, 2012

[26] T.L. Ie, "Malam di Pasar Kumbasari," Dendang Denpasar Nyiur Sanur, Eds. I Nyoman Darma Putra et al, Denpasar: Pemerintah Kota Denpasar bekerja sama dengan Arti Foundation, p. 59, 2012

[27] T.L. Ie, "Lewat Tengah Malam di Kumbasari," Bali The Morning After: Poems about Bali by Bali's Major Poets, Transl. Vern Cork, Darlington: Darma Printing, p. 85, 2000.

[28] L. Mulyadi, "Selamat Malam Kota Denpasar," Dendang Denpasar Nyiur Sanur, Eds. I Nyoman Darma Putra et al, Denpasar: Pemerintah Kota Denpasar bekerja sama dengan Arti Foundation, p. 66, 2012.

[29] K. Nena, "Sanur," Dendang Denpasar Nyiur Sanur. Eds. I Nyoman Darma Putra et al, Denpasar: Pemerintah Kota Denpasar bekerja sama dengan Arti Foundation, p. 69, 2012.

[30] U.L. Paranggi, "Denpasar Selatan, dari Sebuah Lorong...," Eds. I Nyoman Darma Putra et al, Denpasar: Pemerintah Kota Denpasar bekerja sama dengan Arti Foundation, p. 70, 2012.

[31] S. Putra, "Denpasar Kilometer Nol," Eds. I Nyoman Darma Putra et al, Denpasar: Pemerintah Kota Denpasar bekerja sama dengan Arti Foundation, p. 86, 2012.

[32] A.S. Rini, "Sihir Denpasar," Eds. I Nyoman Darma Putra et al, Denpasar: Pemerintah Kota Denpasar bekerja sama dengan Arti Foundation, p. 93, 2012.

[33] M. Ruscitadewi, “Denpasar,” Eds. I Nyoman Darma Putra et al, Denpasar: Pemerintah Kota Denpasar bekerja sama dengan Arti Foundation, p. 99, 2012.

[34] M. Ruscitadewi, "Lewat Tengah Malam di Kumbasari," Bali The Morning After: Poems about Bali by Bali's Major Poets, Transl. Vern Cork, Darlington: Darma Printing, p. 5, 2000.

[35] O. Rusmini, "Sanur," Eds. I Nyoman Darma Putra et al, Denpasar: Pemerintah Kota Denpasar bekerja sama dengan Arti Foundation, p. 101, 2012.

[36] IM. Suantha, "Ekuilibrium Denpasar," Eds. I Nyoman Darma Putra et al, Denpasar: Pemerintah Kota Denpasar bekerja sama dengan Arti Foundation, p. 103, 2012.

[37] W. Sunarta, “Denpasar,” Eds. I Nyoman Darma Putra et al, Denpasar: Pemerintah Kota Denpasar bekerja sama dengan Arti Foundation, p. $111,2012$.
[38] K.L. Syaelendra, "Fragmen Pasar Malam Kumbasari," Eds. I Nyoman Darma Putra et al, Denpasar: Pemerintah Kota Denpasar bekerja sama dengan Arti Foundation, p. 121, 2012

[39] A. Winastri, "Kumbasari," Eds. I Nyoman Darma Putra et al, Denpasar: Pemerintah Kota Denpasar bekerja sama dengan Arti Foundation, p. 132, 2012.

[40] IN. Wirata, "Di Taman Kota, Sebtaang Pohon Tak Kutahu Namanya," Eds. I Nyoman Darma Putra et al, Denpasar: Pemerintah Kota Denpasar bekerja sama dengan Arti Foundation, p. 136, 2012.

[41] A.Z. Noor, "Pasar Kumbasari, Denpasar," Eds. I Nyoman Darma Putra et al, Denpasar: Pemerintah Kota Denpasar bekerja sama dengan Arti Foundation, p. 147, 2012.

[42] O. Rusmini, "Kintamani," Patiwangi, Yogyakarta: Bentang Budaya, p. $120,1974$.

[43] W.Wisatsana, "Jalan ke Tanah Lot," Bali The Morning After: Poems about Bali by Bali's Major Poets, Transl. Vern Cork. Darlington: Darma Printing, p. 71, 2000.

[44] H.Y. Haska, "Jembatan Campuhant," Bali The Morning After: Poems about Bali by Bali's Major Poets, Transl. Vern Cork. Darlington: Darma Printing, p. 109, 2000.

[45] S. Situmorang, "Arak Bali,” Bali The Morning After: Poems about Bal by Bali's Major Poets, Transl. Vern Cork. Darlington: Darma Printing, p. 119, 2000.

[46] N. Parsua, “Kepada Bali,” Pemburu, Denpasar: Lesiba, p. 40, 1987.

[47] N. Parsua, "Batur," Sajak-Sajak Dukana, Denpasar: Lesiba, p. 40-42, 1982.

[48] IG.R. Supandi, "Di Persimpangan Bukit Pecatu," "Malam Terang Bulan di Pantai Kuta," Tuhan Telah Datang Padaku. M. Sukada dan IG.R. Supandi, Denpasar: Lesiba, p. 17, 20, 1975.

[49] IG.R. Supandi, "Pantai Kuta," "Kerambitan," Telah Kubuka Pintu, IG.R. Supandi dan T. Rangkuty, Denpasar: Lesiba, p. 13, 16, 1974

[50] IW. Windia, "Balada Orang ${ }^{2}$ Trunyan," "Sukawati," "Kamasan," Malam Sunyi, Denpasar: Lesiba, p. 8, 9, 14, 1974.

[51] IM.J. Atmaja, "Denpasar," Dengarlah Jiwa Kami Meratap, Denpasar: Lesiba, p. 8, 1973.

[52] M. Taro, "Oleh-Oleh dari Bali," Seekor Burung buat Tarmada, Denpasar: Lesiba, p. 4, 1973.

[53] IG.R. Supandi, "Kemarau di Bukit Pecatu," Adalah Sebagian dari Kita, F. Baraas dan IG.R. Supandi, Denpasar: Lesiba, p. 14, 1973.

[54] F. Baraas, "Di Pelabuhan Buleleng," Adalah Sebagian dari Kita. F. Baraas dan IG.R. Supandi, Denpasar: Lesiba, p. 5, 1973.

[55] N. Parsua, "Bedugul," Setelah Angin Senja Berhembus, Denpasar: Lesiba, p. 5, 1973

[56] N. Sutjipta, "Danau Bedugul," Penyair Bali, Denpasar: Himpunan Pengarang Indonesia Bali, p. 41, 1969

[57] N. Berata, "Sendja di Pantai Buleleng," Penyair Bali, Denpasar: Himpunan Pengarang Indonesia Bali, p. 20, 1969.

[58] Y. Paniek, "Kepada Bali," Penyair Bali, Denpasar: Himpunan Pengarang Indonesia Bali, p. 15, 1969.

[59] F. Baraas, "Kintamani," Penyair Bali, Denpasar: Himpunan Pengarang Indonesia Bali, p. 12, 1969.

[60] G. Dharna, “Kepada Bali," Penyair Bali, Denpasar: Himpunan Pengarang Indonesia Bali, p. 10, 1969. 